counties of England" (Memoirs of the Geological Survey of Great Britain, vol. i. p. 297); Dupont's "Essai d'une Carte Géologique des Environs de Dinant" (Bulle'in de l'Académie Royale de Bruxelles, vol. xx. pp. 9 and ro) ; Réunion' Extracrdinaire de la Socièté Géologique de France à Liège (Bulletin de la Société Géologique, 2 ser., vol. xx. p. 76r); Elie de Beaumont's and Dufrenoy's Explication de la Carte Géologique de la France, vol. i. pp. 240-64; also to Lyell's Elementary Manual of Geology, article, "Denudation ;" and to De la Béché's "Geological Ob erve ," p. 815.

Shoreham, Kent, May 18

JOSEPH PRESTWICH

\section{VOLCANOES AND EARTHQUAKES}

$T H E$ remarkable series of volcanic phenomena which tave lately been exhibited at various parts of the earih's surface within so short a period of time, gives much matter for consideration, and must in due time afford us a rich harvest of facts with which to test the numerous theories which have been started to account for the occurrence of volcanic eruptions and of earthquakes. Even from our at present scanty information we have, I think, s: mething to learn.

First in the series, so far as I am aware, was the very severe earthquake at Independence, Inyo County, California, which took place on Tuesday, March 26, commencing at 2 A.M., and lasting till 7 A.M., during which time "the earth was never for a moment perfectly quiet, and every few minutes heavy shocks, of a few seconds' duration, were occurring; in all there were more than fifty very heavy shocks." This place is only fourteen miles from the Black Rock, a volcano in the Sierra Nevada mountains, "the sides of which are corered with lava, and which is supposed to be an extinct volcano." It is stated that "during the time the shocks were most severe, flashes of light were seen to issue from the top of this mountain, and streams of fire ran down its sides."

The result of this earthquake is summed up in a few words as "the whole country turned topsy-turvy" (Virginia Caty (Nevada) Enterprise).

Then a few days afterwards came the terrific earthquake in Antioch, which commenced on April 3, and continued with greater or less severity, "in Aleppo, and as far east as Orf $\mathrm{t}$, beyond the Euphrates," for more than a week, becoming very severe on April Io; here there appears to have been no actual volcanic phenomenon; but it appears from the letters of the Rev. W. Brown in the Times, that there exists in the immediate neighbourhood a mountain, "the pecu'iar conical form of which is very suggestive of an ancierit volcano."

The latest African news tells us that "Several violent shocks of earthquake had occurred at Accra, on the Gold Coast, on April I4 and I5, causing considerable damage to the place." And as unworted atmospheric disturbances have often been connected with volcanic phenomena, it may not be out of place to mention here the fearful hurricane-which wrecked every vessel but one in the Harbour of Zanzibar on April I5.

And then on April 24 began the recent eruption of Vesuvius, which will be for ever memorable, not only on account of its magnitude and grandeur, but also, and still most so, by reason of the amazing intrepidity of the man, who, from a pure love of science, remaincd at his post, like the gatekeeper of Pompeii, throughout the whole of that terrible time, but happily was not, like that heroic soldier, buried in a shower of ashes; the world was spared the loss.

Now is there any connection between these phenomena exhibited in so distant parts of the earth's surface? One thing is certain, namely, that within the short space of a month all this has occurred, and one can hardly help thinking that somehow or other these volcanic countries must be connected underground; it has long been thought that Etna and Vesuvius are points on a volcanic area which passes nortli-west to the
Eifel, Auvergne, and Iceland ; has the neighbourhood of Antioch, with its unenviable notoriety for earthquakes, or the West African coast, anything to do with this area? But if so, what shall we say of the Sierra Nevada, why should its volcanoes be active at the same time? Why should the country there be "turned topsyturvy" by earthquakes?

While pointing out these coincidences, we must not jump too hastily to conclusions from them; for on the one hand we are told that although the Antioch earthquake extended so far east, yet, to the nortb and south, even at a few miles' distance, nothing whatever was observed, and, on the other hand, that the Californian earthquake was of so superficial a character that "at Hot Springs, while severe shocks were felt on the surface, the men in the mines, 200 feet deep, felt nothing of them." Now the evidence goes to show that the latter earthquake was directly connected with the eruption of a volcano in the neighbourhood, so that, although the origin of the disturbance may be underground, possibly at a very considerable depth, the shocks are at a certain distance quite superficial, and moreover are transmitted in certain definite directions.

Taking all these facts togetber, they would rather seem to favour the conclusions that at any rate a great many, if not all, of the volcanic regions of the world are connected, and that they are not merely parts of the earth's surface which happen to be over isolated subterranean furnaces, but places where access to the exterior is more easy for the molten matter which lies underneath a great part, perhaps all, of the earth's crust. I must not be understood to be upholding the (shall I say exploded?) theory of the internal fluidity of the earth; I merely mean to point out that such coincidences in point of tinie ought to make one hesitate before rushing to the other extreme, and looking upon volcanoes as mere local eccentricitjes.

But it will be said, if there is any general commotion under even the volcanic area of Europe, why do not the extinct vollcanoes of Auvergne break out again? Here is a difficulty which is not at all solved by the sugges. tion that at first occurs to one, that as the raising of the country has drained the enormous lakes, on the borders of which these volcanoes stood, there is no longer a supply of water to rouse them into action, for are there not lakes stijl in the Eifel, nay, are not those lovely lakes actually in the craters of extinct volcanoes?

Again, who has seen the wonderful natural harbcur of Messina from the high ground above the town without believing it to be an extinct submerged crater? If there be still liquid rock below these craters, it may be that they are no longer the points of least resistance. And this is the probable explanation of their inactivity ; for it must not be imagined that an eruption of Etna or of $\mathrm{Ve}$ suvius, or of any other volcano, necessarily means an ejection of ashes, lava, \&c., from the crater, or from any crater; not at all, the weakest point in the vicinity gives way, and thus we have the numerous cones formed which surround every considerable volcano for some distance.

The mention of Auvergne leads me to make a few rimarks on the disputed point, as to whether or not the volcanoes in that country have been in eruption within historic times, especially as I see that a correspondent in last week's NATURE has come to the conclusion originaliy drawn by "an eminent historian and antiquary, Sir Francis Palgrave," as long ago as 1844 , and adopted by theological writers ever since, that because a bishop of Vienne $\epsilon$ stablished Rogation days on account of some alarming terrestrial phenomena which happened in his diocese, therefore the volcanoes of Auvergne were in action at the time. We have two documents which refer to this matter, a letter written by Sidonius Apollinaris (who lived in the very centre of the Chaine des 
Puys, and on the border of a lake which was actually formed by the damming up of a stream by one of the most recent of the lava-currents) to Mamertus, Bishop of Vienne, in which he speaks of the earthquakes that had occurred in the neighbourhood of Vienne; of fire issuing from the earth and wild beasts taking refuge in cities; and the Rogation Homily of Alcimus Avitus, the successor to Mamertus, which mentions the same catastrophes.

Now in the first place Vienne is more than seventy miles in a direct line from the more recent Auvergne volcanoes; in the next, Sidonius himself makes no mention in his writings of any eruptions having taken place in his neighbourhood, although he wrote poems describing the beauty of the scenery; and lastly Auvergne is not mentioned by any ancient writer, neither by Cæsar, who encamped there and laid siege to Gergovia, a city situated on a table-land, with craters close at hand in almost every direction; nor by Pliny, who gives a list of all the then known volcanic countries, including some very out-of-theway ones; nor by Strabo, nor by any of the poets, as a country where volcanoes were ever known to have been in action.

For these reasons, and because no volcano could have burst out near Vienne without leaving some traces of its existence, Dr. Daubeny concluded that the bishops of Gaul alluded to earthquakes; especially as "the underground thunder, the opening of fissures in the ground, the bursting out of flames and gases, the projection of water and of stones, the smell of sulphur, the alarm evinced by the animals of the spot and neighbourhood, the elevation or depression of the land, noticed by Sidonius and by Avitus in the passages referred to by Sir Francis Palgrave, are all reported as concomitants of the great earthquakes which have occurred in more recent times." Geologists have since accepted this conclusion as the correct one, in opposition to what I may call the theological position.

There was, however, a volcanic region which had not been visited by any English geologist, and which had not been described, viz., the basin of Montbrison, through which the Loire flows. Of this Mr. Scrope says in his work (2nd Ed., p. 28), "a further examination of this basin seems very desirable;" now as this district lies about half way in a direct line between the "Puys," about Clermont Ferrand and Vienne, it occurred to Dr. Daubeny that the disturbances spoken of as in the neighbourhood of Vienne, might have taken place around Montbrison, and accordingly in the autumn of I 866 he visited that locality, and I had the honour of accompanying him on the occasion. We examined carefully the volcanic hills of the neighbourhood, and could find no trace of recent volcanic eruptions ; in his own description of this expedition published in the Quarterly Fournal of Science for January 1867 , and republished in his "Miscellanies" (vol. i. p. 74), just before his death, he says :-

"I am now prepared to say that, without pretending to have surveyed the entire district, I saw enough to convince me that no volcanic disturbance which had occurred within this area at so late a period as that alluded to could have escaped our notice, and that every indication of igneous action which presents itself throughout the country, bears marks of a much greater antiquity.

"Thus much, at least, I can venture to affirm, namely, that neither, craters, streams of lava, scoriæ, nor even cellular trap, are to be met with anywhere within the limits of this district. On the contrary, the only igneous rocks which came under our observation consisted of a compact basalt, containing nests of olivine, a material which could only have been elaborated by the aid of great pressure, and under a different configuration of the surface from that now existing."

The Doctor therefore reiterated his statement that "the lively" picture drawn by Sidonius" should not "be regarded in any other light than as the offspring of a lively imagination, dwelling upon reports which had reached the author with respect to some fearful earthquake which may have occurred in the neighbourhood of Vienne."*

I will conclude by advising those who wish to study volcanic phenomena to go to Auvergne, they can do so at almost any time of the year, mid-winter, when it is far too cold for comfort, being the exception; they will there see resulis of volcanic action far more varied and instructive than at Vesuvius or even at Etna, and they will also be able to study the effects of denudation on a gigantic scale. Few geologists seem to appreciate the fact that within 24 hours of London is one of the largest, richest, and most beautiful of the volcanic countries in Europe.

\section{W. H. CORFIELD}

\section{PHOTOGRAPHY AS AN AID TO SCIENCE}

$T$ HE applications made of photography now-a-days are as various as they are numerous. Irrespective of the ordinary every-day uses to which the art is put in reproducing scenes and objects, or pandering to human vanity, there are, as we know, numberless ways in which it is constantly being employed as a faithful handmaiden to science. To the chemist, the surgeon, the engineer, and others, its aid is frequently of considerable importance, while to the astronomer and physicist the assistance it renders is at times indispensable. The accuracy and fidelity with which the pencil of light performs its functions, combined with the facility with which such reliable records are obtained, make photography indeed one of the greatest boons at the disposal of scientific men.

Let us take, for example, the solar records which are daily secured at the Kew Observatory. These photographs of the sun's disc, taken whenever practicable at a certain fixed period in the day, are often of considerable value, and form illustrations, as it were, of other scientific observations made at the same time. A series of prints of this kind, secured day after day, afford, in truth, a most interesting and instructive lesson to the student of astronomy, for the characteristics exhibited by the various photographs may serve as a corroboration, or otherwise, of scientific theories based upon other data and results. The nature and luminosity of the markings, or spots, upon the disc are rendered with unerring fidelity, and the way in which these are continually modified in shape and intensity, as likewise the rapidity with which they are seen to travel across from the east to west limb of the sun, to reappear again some twelve days afterwards upon the eastern edge; is all clearly and distinctly shown.

Again, another interesting application of photography to astronomic purposes is to be found in the reproduction of the stars as recently undertaken by Prof. Rutherford. In this instance the objects to be secured are so minute that special precautions are necessary in depicting them upon the sensitive film, so that their impressions may be distinguishable from accidental specks in the collodion plate. To prevent any such chance of mistake, Prof. Rutherford secures a double image of each luminary, the moving telescope to which the miniature camera is attached being halted for a short time (half a minute) between a first and second exposure of the plate, so that each star is represented by a double speck, so to speak, upon the negative, and is clearly to be distinguished therefore, from any accidental defect in the film; moreover, by. stopping the telescope again after the period necessary for the second exposure, the professor is enabled to demonstrate the direction in which the stars are moving, for the brightest of them produce a tiny streak of light during the time that the camera remains perfectly still. A map or plan of the heavens is in this

* Those who wish for further information will find the whole subject discussed in Dr. Daubeny's classical work on Volcanoes, and in his papers in the Qucrterly Fournal of Science for April 1866 and January 1867 , 